[Original]

\title{
Effect of Mite Antigens on Antigen Presenting Cells/ Macrophages in Mice
}

\author{
Junko NOGUCHI ${ }^{1}$ Etsushi KurODA ${ }^{1}$, Kazuhisa ONO$^{2}$ and Uki YaMASHITA ${ }^{1}$ \\ ${ }^{1}$ Department of Immunology, School of Medicine, University of Occupational and Environmental Health, \\ Japan. Yahatanishi-ku, Kitakyushu 807-8555, Japan \\ ${ }^{2}$ Department of Fermentation Technology, Faculty of Engineering, Hiroshima University. \\ Higashihiroshima 739-8527, Japan
}

Abstract: The effect of mite antigens on murine lymphocytes and macrophages was studied in vitro. Antigens prepared from Dermatophagoides farinae bodies（Dfb）or recombinant Mag3, glutathione-S transferase (GST)-fused mite antigen, stimulated murine spleen cells to proliferate. The responder cells were B cells, because the response was sensitive to anti-Ig antibody and $C$ treatment, but not to anti-Thy 1 antibody and $\mathrm{C}$ treatment. The response was not due to lipopolysaccharide contamination, a representative B cell mitogen, because polymyxin B column-passed Dfb significantly stimulated B cells, and GST protein alone did not stimulate them. Alloantigen presenting activity was increased in mite antigen-treated B cells and spleen adherent cells. Mite antigens stimulated CD80 and the major histcompatibility complex (MHC) class II molecule expression, but suppressed CD86 expression on B cells and spleen adherent cells that were detected by a flow cytofluorometer. Antibodies to the MHC class II molecules, CD80 and CD86 blocked the alloantigen-presenting activity. Furthermore, mite antigens stimulated B cells and spleen adherent cells to produce cytokines. These results suggest that mite antigens have a stimulating activity on antigen-presenting cells/ macrophages and modulate immune responses.

Key words: mite antigen, antigen-presenting cell, cytokine, costimulatory molecule.

(Received 15 May 2000, accepted 11 July 2000 )

\section{Introduction}

Allergens from house dust mites, Dermatophagoides, are major agents causing allergic disorders such as bronchial asthma, atopic dermatitis and perennial rhinitis [1]. The characterization of mite antigens has been made by biochemical, immunological and genetic engineering methods $[2,3]$. Recently, cDNAs coding for major and important mite antigens have been cloned and the corresponding recombinant antigens have become available. The human and murine $\mathrm{T}$ cell-reactive region on Der $\mathrm{p} 1$ and Der $\mathrm{p} 2$ have been identified 
using recombinant truncated fusion proteins, synthetic peptide, and/or T cell clones. Dr. Ono et al . have cloned four cDNAs coding for additional important allergens from $D$. farinae library which were referred to as mite antigen gene (mag) $1,3,29$ and $44[4-8]$. The recombinant antigens, Mag1, Mag3 and Mag44, bound with considerably high frequencies to IgE antibody in the sera from patients with bronchial asthma and showing positive skin reactions to mite and house dust extracts, while Mag29 reacted to IgE antibody to a less extent [5]. Recombinant Mag1 and Mag3 stimulated T cells from mite-sensitive patients to proliferate $[9,10]$. However, their biological activities were not fully analyzed. Previously, we reported that crude mite antigens, Dfb and Dff, have a potent B cell mitogenic activity in mice [11]. In this study, we investigated the effect of mite antigens on antigen presenting cells/macrophages from the standpoint of the production of cytokines and the expression of costimulatory molecules.

\section{Materials and Methods}

Mice

$\mathrm{C} 3 \mathrm{H} / \mathrm{HeN}$ and BALB/c mice were obtained from Seac Yoshitomi Experimental Animal Co. (Yoshitomi, Oita, Japan) and maintained on purina rodent chow and water ad libitum. Male mice were used at 8-12 weeks of age.

\section{Mite antigens}

D. farinae were cultured on purina rodent chow (Oriental Yeast Co. Tokyo, Japan) at $37^{\circ} \mathrm{C}$ for 30 days. A whole mite culture was suspended in a saturated $\mathrm{NaCl}$ solution and centrifuged at $1400 \times \mathrm{g}$ for $30 \mathrm{~min}$. The floating mites were collected by filtration and ground with quartz in $10 \mathrm{mM}$ phosphate-buffered saline, $\mathrm{pH}$ 7.2(PBS) and then centrifuged. The solubilized fraction was used as a body antigen. The antigen fraction was dialyzed and lyophilized. The freeze-dried extracts were referred to as Dfb. To exclude the contamination of lipopolysaccharide (LPS) in Dfb, Dfb was passed through a polymyxin B-Sepharose column [12].

Recombinant antigen was purified as described previously [8]. Briefly, an expression plasmid carrying mag 3 was constructed on a plasmid pGEX-2T (Pharmacia Biotech, Uppsala, Sweden) and transformed into Escherichia coli JM105. Isopropyl- $\beta{ }_{-\mathrm{D}}$-thiogalactoside (IPTG) -induced cells in $2 \ell$ of culture were harvested and disrupted by sonication in PBS. Purified GST-Mag3 $(66 \mathrm{kD})$ protein was obtained by passing it through a glutathioneSepharose 4B (Pharmacia Biotech) column or by preparative disk gel electrophoresis (model NA-1800; Nippon Eido, Tokyo, Japan).

\section{Preparation and fractionation of spleen cells}

A spleen cell suspension was prepared from normal mice and treated with $0.83 \% \mathrm{NH}_{4} \mathrm{Cl}$ 
in $0.017 \mathrm{M}$ Tris buffer, $\mathrm{pH} 7.2$, to lyse red blood cells. Four ml of spleen cell suspension $\left(5 \times 10^{6} / \mathrm{ml}\right.$ ) with RPMI 1640 (Nissui Seiyaku Co., Tokyo, Japan) containing $10 \%$ fetal calf serum (FCS, Grand Island Biological Co., Gland Island, NY, USA) was incubated in 60 mm plastic culture dishes (Falcon \#3002, Becton Dickinson Co., Lincoln Park, NJ, USA) at $37^{\circ} \mathrm{C}$ for $2 \mathrm{~h}$ in $5 \% \mathrm{CO}_{2}$ and $95 \%$ air. After incubation, nonadherent cells were discarded by gentle agitation with PBS. The adherent cells were obtained by scraping with a rubber policeman. The purity of adherent cells was $<10 \% \operatorname{IgM}^{+}$cells and $<5 \%$ Thy $1^{+}$cells as determined by flow cytometry.

Purified B cells were prepared by passing spleen cells through a Sephadex G-10 column (Pharmacia Biotech) after treating the spleen cells with anti-Thy 1.2 antibody and rabbit complement (C, Cedarlane Laboratories, Ontario, Canada) at $37^{\circ} \mathrm{C}$ for $1 \mathrm{~h}$. The purity of $\mathrm{B}$ cells was $>95 \%$.

Purified $\mathrm{T}$ cells were prepared by passing spleen cells through a nylon column as described previously [13]. The purity of T cells was $>95 \%$.

\section{Assay of proliferative response of spleen cells}

Spleen cells $\left(2 \times 10^{5}\right)$ were cultured with mite antigens, Dfb $(25 \mu \mathrm{g} / \mathrm{ml})$, Mag3-GST $(12.5 \mu \mathrm{g} / \mathrm{ml})$, LPS $(10 \mu \mathrm{g} / \mathrm{ml}$, Sigma Chemical Co., St. Louis, MO. USA), or GST (12.5 $\mu \mathrm{g} / \mathrm{ml}$ ) in Enriched Hanks Amino Acid (EHAA) medium containing 10\% FCS as described by Corradin et al. [14] in wells of flat-bottomed microtiter culture plates (Falcon \#3072, Becton Dickinson Co.) at $37^{\circ} \mathrm{C}$ for 3 days in $5 \% \mathrm{CO}_{2}$ and $95 \%$ air. The cells were labeled during the last $18 \mathrm{~h}$ with $18.5 \mathrm{kBq}$ of tritiated thymidine $\left(\left[{ }^{3} \mathrm{H}\right]-\mathrm{TdR}\right.$, specific activity, 222 $\mathrm{Gbq} / \mathrm{mmol}$, Amersham International plc, Buckinghamshire, UK) and were harvested using a semi-automated cell harvester (Abe Kagaku Co., Chiba, Japan). The amount of radioactivity incorporated into DNA in the lymphocytes was measured with a liquid scintillation spectrophotometer (Aloka, Tokyo, Japan) [15]. The results are expressed as the mean counts per minute $(\mathrm{cpm})$ of $\left[{ }^{3} \mathrm{H}\right]-\mathrm{TdR}$ incorporated by lymphocytes with standard error in triplicate cultures.

\section{Allogeneic mixed lymphocyte reaction}

Spleen adherent cells from $\mathrm{C} 3 \mathrm{H} / \mathrm{HeN}\left(\mathrm{H}-2^{\mathrm{k}}\right)$ mice were cultured with mite antigens at $37^{\circ} \mathrm{C}$ for $18 \mathrm{~h}$, treated with $100 \mu \mathrm{g} / \mathrm{ml}$ of Mitomycin C(Kyowa Hakko Kogyo Co., Tokyo, Japan), washed, and then cultured $\left(5 \times 10^{4}\right)$ with $2 \times 10^{5}$ responder T cells from BALB/c $(H-$ $2^{\mathrm{d}}$ ) mice in EHAA medium containing $10 \% \mathrm{FCS}$ in flat-bottomed microtiter culture plates at $37^{\circ} \mathrm{C}$ for 6 days in $5 \% \mathrm{CO}_{2}$ and $95 \%$ air. The cells were labeled and harvested as described above.

\section{Flow cytometric analysis}

Spleen adherent cells $\left(1 \times 10^{6}\right)$ were incubated on ice for $30 \mathrm{~min}$ with a saturating amount 
of fluorescein conjugated anti-CD80 (clone 1G10), CD86 (clone GL1), I-A (clone 14V. 18) and Mac-1 (clone BL-N/G1, Cosmo Bio Co., Tokyo, Japan). After incubation, cells were washed with PBS and analyzed by EPIX XL (Coulter Co., Healea, FL, USA). At least 10,000 cells were counted for each sample. The results were expressed as the percentage and the profile of fluorescence-positive cells.

\section{Production and assay of cytokines}

Spleen adherent cells and B cells $\left(5 \times 10^{5} / \mathrm{ml}\right)$ were cultured with mite antigens in RPMI 1640 medium containing $10 \%$ FCS in 24 well culture plates (Falcon \#3047, Beckton Dickinson Co.) at $37^{\circ} \mathrm{C}$ for $20 \mathrm{~h}$, and the culture supernatants were harvested. Cytokines in the culture supernatant were assayed by enzyme-linked immunosorbent assay (ELISA) as described previously [16] using anti-mouse cytokine monoclonal antibodies, biotin-labeled anti-cytokine monoclonal antibodies and streptoavidin-conjugated alkaline phosphatase (Pharmingen, San Diego, CA, USA) and p-nitrophenylphosphate (Zymed Laboratory Inc., San Francisco, CA, USA) as a substrate. The results were expressed as mean ng of cytokines produced by $5 \times 10^{5}$ cells in duplicate cultures comparing with recombinant cytokines (Pharmingen) as the standard.

\section{Analysis of cytokine $m R N A$ expression}

Purified B cells $\left(10^{6} / \mathrm{ml}\right)$ were stimulated with LPS or mite antigens at $37^{\circ} \mathrm{C}$ for $6 \mathrm{~h}$. Expression of cytokine mRNA was detected by semi-quantitative RT-PCR. Total cellular RNA was extracted by an acid guanidinium thiocyanate-phenol-chloroform extraction procedure [17]. First strand cDNA was synthesized from $5 \mu \mathrm{g}$ of the total RNA by Superscript $^{\mathrm{TM}}$ II RNase $\mathrm{H}^{-}$reverse transcriptase (Life Technologies Inc., Rockville, MD, USA) as instructed by the manufacturer using $0.25 \mu \mathrm{g}$ of random primer (Life Technologies Inc.). One -tenth of the synthesized cDNA was amplified by PCR using $50 \mathrm{pmol}$ sense and anitsense primers with 1 unit of Taq polymerase (Boehringer Mannheim GmbH, Mannheim, Germany) in a total volume of $50 \mu \mathrm{l}$. The reaction buffer consisted of $10 \mathrm{mM}$ Tris- $\mathrm{HCl}, \mathrm{pH} 8.3,50$ $\mathrm{mM} \mathrm{KCl}, 1.5 \mathrm{mM} \mathrm{MgCl}_{2}, 0.25 \mathrm{mM}$ dNTP. PCR cycles were performed for $1 \mathrm{~min}$ at $94^{\circ} \mathrm{C}$ for denaturation, $1 \mathrm{~min}$ at $55^{\circ} \mathrm{C}$ for annealing and $2 \mathrm{~min}$ at $72{ }^{\circ} \mathrm{C}$ for extension, and at the first cycle denaturation was run for $2 \mathrm{~min}$ at $94^{\circ} \mathrm{C}$. The sequences of the sense and antisense primers of IL- $1 \alpha$, IL- 6 and $\beta$-actin were ( 5' -ATGGCCAAAGTTCTTGACTTGTTT-3' , 5' CCTTCACCCAACACGGGCTGGTC-3'), ( 5'-GACAACCACGGCCTTCCCTA-3', 5' GGTACTCCAGAAGACCAGAGGA-3') and ( 5 '-GTGGCTCCGCTCTAGGCACCAA-3', 5' -CTCTTTGATGTCACGCACGATTTC-3'), respectively. The product size of IL-1 $\alpha$, IL-6 and $\beta$-actin was 625,303 and 360 base pairs, respectively. The PCR cycle of IL-1 $\alpha$ was 38 , IL-6, 29 and $\beta$-actin, 28. A $10 \mu \mathrm{l}$ of PCR products was electrophoresed using a $1.5 \%$ agarose gel. After ethidium bromide staining (Sigma Chemical Co.), PCR products were visualized by UV illumination. 


\section{Statistical analysis}

All experiments were repeated at least three times, and one representative result is shown in Tables and Figures. Statistical analysis was performed by the Student's t test. A confidence level of $<0.05$ was considered significant $[18]$.

\section{Results}

Mitogenic activity of mite antigens on spleen cells

At first, we studied the effect of mite antigens on the proliferative response of spleen cells. Crude mite antigen, Dfb, and recombinant antigen, Mag3-GST, and LPS, as a control mitogen, significantly stimulated normal spleen cells to proliferate at the concentration of $25 \mu \mathrm{g} /$ $\mathrm{ml}, 12.5 \mu \mathrm{g} / \mathrm{ml}$, and $10 \mu \mathrm{g} / \mathrm{ml}$, respectively (Fig. 1). In order to exclude the contamination of LPS in the antigen fraction, we passed Dfb through a polymyxin B-Sepharose column (Dfb-PMB-S). This Dfb still retained its stimulating activity. On the other hand, the LPS response was markedly reduced by PMB-S column passing. Furthermore, GST protein
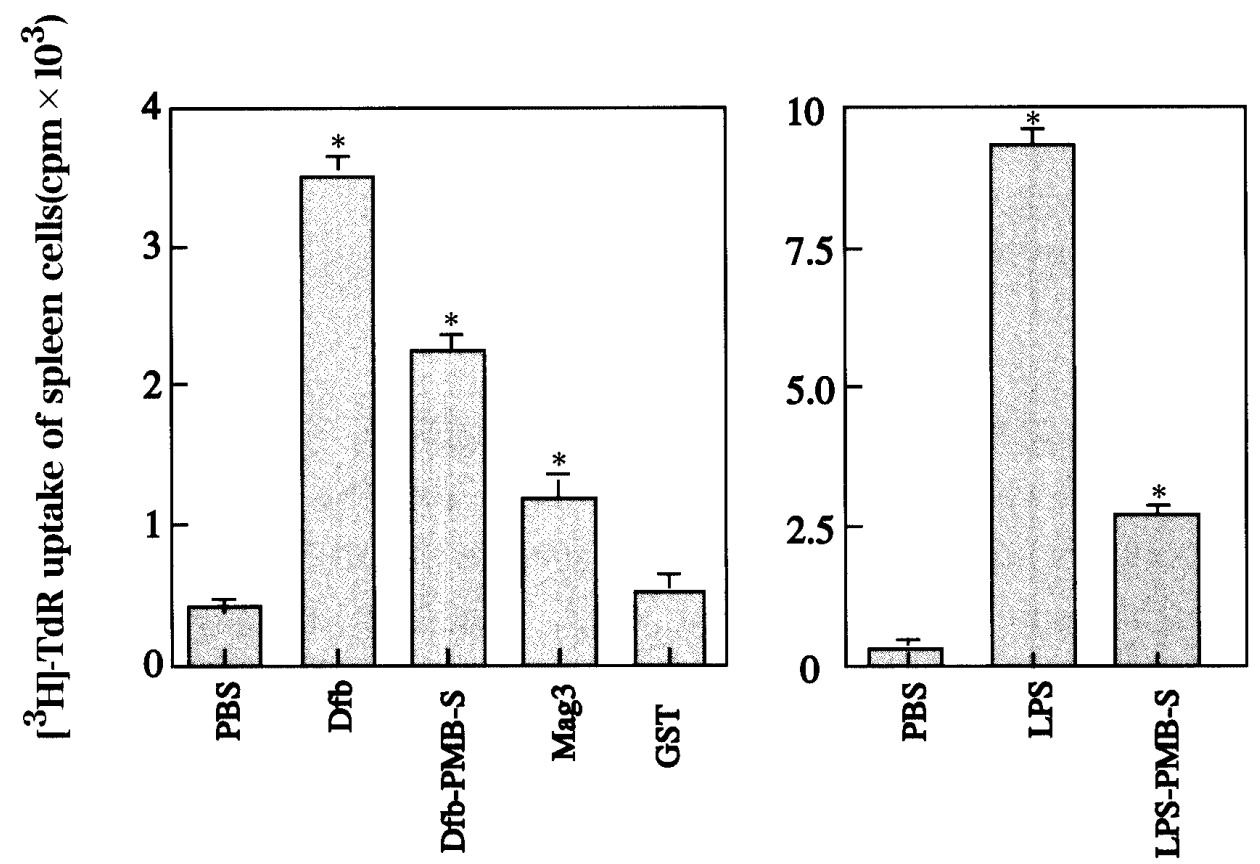

\section{cultured with}

Fig. 1. Stimulating activity of mite antigens on murine spleen cells. Spleen cells $\left(2 \times 10^{5}\right)$ were cultured with $25 \mu \mathrm{g} / \mathrm{ml} \mathrm{Dfb}$, PMB-S passed Dfb, $12.5 \mu \mathrm{g} / \mathrm{ml} \mathrm{Mag} \mathrm{3-GST,} 12.5 \mu \mathrm{g} / \mathrm{ml} \mathrm{GST,} 10 \mu \mathrm{g} / \mathrm{ml} \mathrm{LPS} \mathrm{or}$ PMB-S-passed LPS at $37^{\circ} \mathrm{C}$ for 3 days. The cells were pulsed with $18.5 \mathrm{kBq}$ of $\left[{ }^{3} \mathrm{H}\right]-\mathrm{TdR}$ for the last $18 \mathrm{~h}$ and harvested. $\left[{ }^{3} \mathrm{H}\right]-\mathrm{TdR}$ incorporated by spleen cells was counted by a liquid scintillation spectrophotometer. The results are expressed as the means $\pm \mathrm{SE}$ of cpm of $\left[{ }^{3} \mathrm{H}\right]-\mathrm{TdR}$ incorporated by spleen cells in triplicate cultures.

*significantly stimulated. 


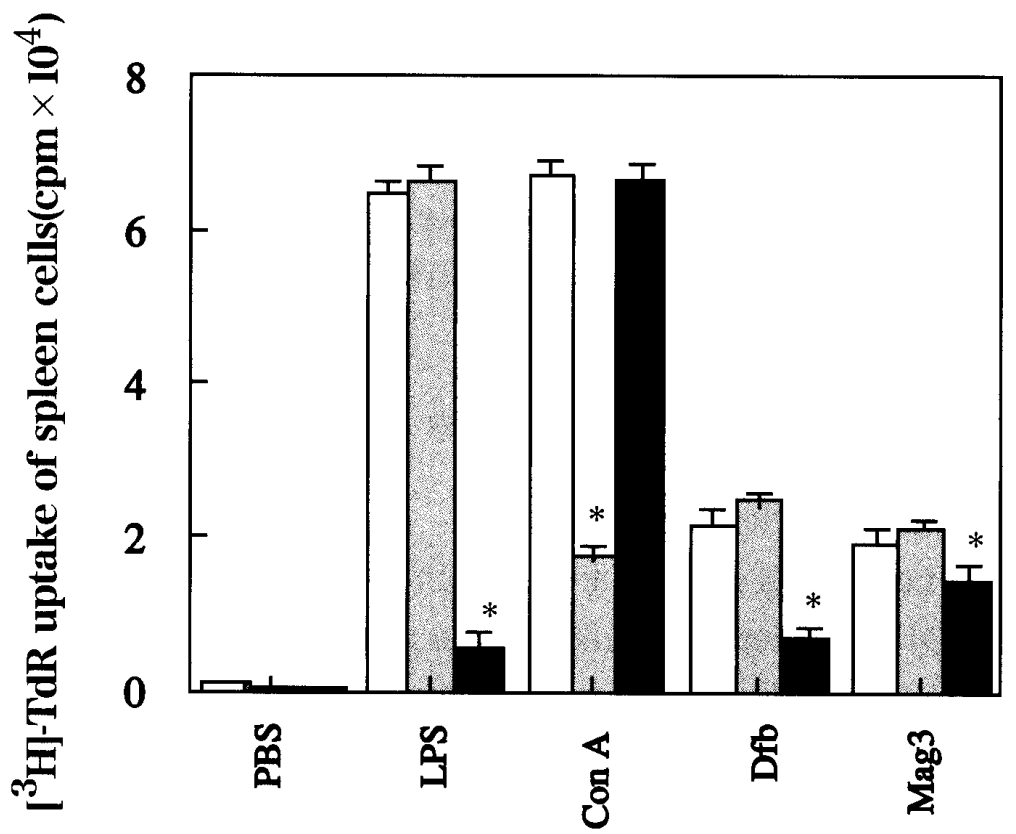

\section{cultured with}

Fig. 2. Responder cells are B cells for the stimulation with Dfb and Mag3. Spleen cells $\left(2 \times 10^{5}\right)$ treated with $\mathrm{C}$ alone $(\square)$, anti-Thy-1 antibody and $\mathrm{C}(\square)$ or anti-Ig antibody and $\mathrm{C}(\boldsymbol{\square})$ were cultured with $10 \mu \mathrm{g} / \mathrm{ml}$ LPS, $10 \mu \mathrm{g} / \mathrm{ml}$ Con A, $25 \mu \mathrm{g} / \mathrm{ml}$ Dfb or $12.5 \mu \mathrm{g} / \mathrm{ml} \mathrm{Mag3-GST}$, for 3 days, and [ $\left.{ }^{3} \mathrm{H}\right]$ TdR incorporation was examined.

*significantly reduced from the group of $\mathrm{C}$ alone.

alone as the control of Mag3-GST had no stimulating activity. To determine the responder cells to mite antigens, we fractionated spleen cells using anti-Thy 1 or anti-Ig antibody and C treatment. As shown in Fig. 2 , control cells responded well to Con A, T cell mitogen, LPS, B cell mitogen, and mite antigens, Dfb and Mag3. Anti-Thy 1 antibody and $C$ treatment reduced the Con A response, but not the LPS response. Anti-Ig antibody and C treatment reduced the LPS response, but not the Con A response. The mite antigen responses were reduced by anti-Ig and $C$ treatment, but not by anti-Thy 1 antibody and $C$ treatment. These results suggest that the major responder cells for mite antigens are $\mathrm{B}$ cells, but not $\mathrm{T}$ cells. Dfb and Mag3 also stimulated Ig production by B cells (data not shown).

\section{Alloantigen presenting activity of $B$ cells and spleen adherent cells treated with mite antigens}

Next, we studied the antigen presenting activity of $\mathrm{B}$ cells, another function of B cells. B cells from $\mathrm{C} 3 \mathrm{H} / \mathrm{He}$ mice were cultured with mite antigens at $37^{\circ} \mathrm{C}$ overnight, and then the alloantigen presenting activity to $\mathrm{T}$ cells from BALB/c mice was studied. Dfb and Mag3treatment enhanced the alloantigen presenting activity of $B$ cells (Table 1). A similar result was obtained using spleen adherent cells as another source of antigen presenting cells. 
Table 1. Effect of mite antigens on alloantigen-presenting activity of spleen adherent cells

\begin{tabular}{ccc}
\hline $\begin{array}{l}\text { Antigen-presenting cells } \\
\text { stimulated with }\end{array}$ & \multicolumn{2}{c}{$\left[{ }^{3} \mathrm{H}\right]-$ TdR uptake by T cells } \\
B cells & Spleen adherent cells \\
\hline PBS & $2766 \pm 845$ & $327 \pm 43$ \\
LPS & $3090 \pm 415$ & $5440 \pm 486^{*}$ \\
Dfb & $7937 \pm 278^{*}$ & $3151 \pm 810^{*}$ \\
Mag3 & $4646 \pm 241^{*}$ & $1015 \pm 174^{*}$ \\
GST & $3356 \pm 87$ & $247 \pm 31$ \\
\hline
\end{tabular}

$\mathrm{B}$ cells and spleen adherent cells from $\mathrm{C} 3 \mathrm{H} / \mathrm{HeN}$ mice were incubated with $10 \mu \mathrm{g} / \mathrm{ml} \mathrm{LPS}, 25 \mu \mathrm{g} / \mathrm{ml}$ $\mathrm{Dfb}, 12.5 \mu \mathrm{g} / \mathrm{ml} \mathrm{Mag} 3-\mathrm{GST}$ or $12.5 \mu \mathrm{g} / \mathrm{ml} \mathrm{GST}$ for $18 \mathrm{~h}$, then treated with $50 \mu \mathrm{g} / \mathrm{ml}$ mitomycin C for 1h. After washing, $5 \times 10^{4}$ cells were mixed with $2 \times 10^{5} \mathrm{~T}$ cells from BALB $/ \mathrm{c}$ mice, cultured for 6 days, and $\left[{ }^{3} \mathrm{H}\right]-\mathrm{TdR}$ incorporated by $\mathrm{T}$ cells was counted. The results are expressed as cpm of $\left[{ }^{3} \mathrm{H}\right]-\mathrm{TdR}$ incorporated by $\mathrm{T}$ cells and SE in triplicate cultures. * significantly enhanced from the group of PBS.

These alloantigen presenting activities were blocked with anti-I- $\mathrm{A}^{\mathrm{k}}$, anti-CD80 and anti-CD 86 antibodies (Fig . 3 ), suggesting that the antigen-presenting activity is mediated by these molecules.

\section{Effect of mite antigens on cytokine production by $B$ cells and spleen adherent cells}

Antigen-presenting activity is mediated by cytokines and adhesion molecules. Therefore, we studied the effect of mite antigens on cytokine production. Purified B cells and spleen adherent cells were stimulated with mite antigens for $18 \mathrm{~h}$, and the production of IL- $1 \alpha, \mathrm{IL}-6$, IL-10 and IL-12 in the culture supernatant was assayed by ELISA. Dfb and Mag3 markedly induced these cytokines on spleen adherent cells, while control protein, GST did not (Table 2 ). Purified B cells produced a small amount of IL-10, but did not produce any other cytokines (Table 2 ). However, by RT-PCR, cytokines such as IL-1 $\alpha$ and IL-6 were detected in B cells after the stimulation with Dfb and Mag3 (Fig. 4 ). We also confirmed that Dfb-PMB$\mathrm{S}$ had a similar activity to Dfb (data not shown).

\section{Effect of mite antigens on cell surface marker on $B$ cells and spleen adherent cells}

Following the culturing of spleen adherent cells with mite antigens for $18 \mathrm{~h}$ at $37^{\circ} \mathrm{C}$, the expression of CD80, CD86 and I-A ${ }^{k}$ on the spleen adherent cells was detected by a flowcytometer. As shown in Fig. 5 , spleen adherent cells cultured with PBS expressed $42 \%$ CD80, $77 \%$ CD86 and $82 \% \mathrm{I}-\mathrm{A}^{\mathrm{k}}$. The culture of spleen adherent cells with Dfb enhanced the expression of CD80 and I-A ${ }^{k}$, but reduced the expression of CD86. Similar results were obtained using purified $\mathrm{B}$ cells. 


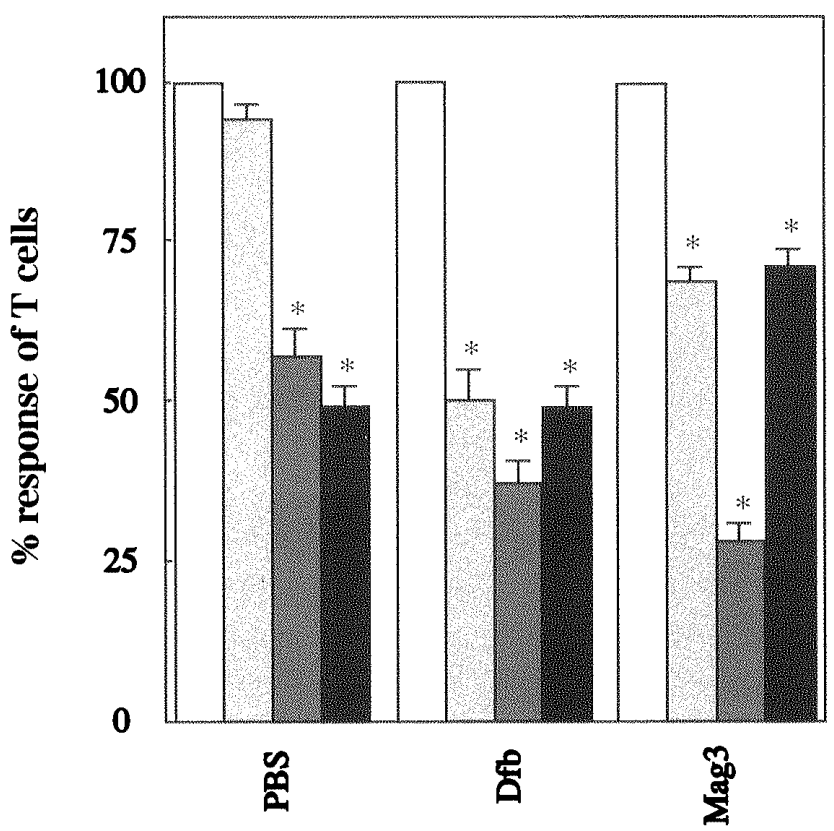

cultured with

Fig. 3. Effects of anti-CD80, anti-CD86 or anti-I-A ${ }^{k}$ antibodies on allogeneic MLR. Spleen adherent cells from $\mathrm{C} 3 \mathrm{H} / \mathrm{HeN}$ mice were cultured with $25 \mu \mathrm{g} / \mathrm{ml} \mathrm{Dfb}, 12.5 \mu \mathrm{g} / \mathrm{ml} \mathrm{Mag} \mathrm{3-GST}$ or PBS for $18 \mathrm{~h}$, and treated with $50 \mu \mathrm{g} / \mathrm{ml}$ mitomycin $\mathrm{C}$ for $1 \mathrm{~h}$. After washing, $5 \times 10^{4}$ cells were incubated with PBS $(\square)$, anti-CD $80(\square)$, anti-CD-86 $(\square)$ or anti-I-A $(\square)$ antibody $(1 \mu \mathrm{g} / \mathrm{ml})$ for $30 \mathrm{~min}$, mixed with $2 \times 10^{5} \mathrm{~T}$ cells from BALB/c mice, and cultured for 6 days, and $\left[{ }^{3} \mathrm{H}\right]-\mathrm{TdR}$ incorporated by $\mathrm{T}$ cells was counted. The results are expressed as percentage of $\mathrm{T}$ cell response in the presence of antibody when assuming that the $\mathrm{T}$ cell response without antibody is $100 \%$.

*significantly suppressed.

Table 2. Effect of mite antigens on cytokine production by spleen adherent cells or B cells

\begin{tabular}{|c|c|c|c|c|c|}
\hline \multirow{2}{*}{$\begin{array}{l}\text { Stimulated } \\
\text { with }\end{array}$} & \multicolumn{4}{|c|}{ Spleen adherent cells } & \multirow{2}{*}{$\frac{\text { B cells }}{\text { IL }-10}$} \\
\hline & $\mathrm{IL}-1 \alpha$ & IL-6 & IL-10 & $\mathrm{IL}-12$ & \\
\hline PBS & 3265 & 433 & 37 & 365 & 8 \\
\hline LPS & 98565 & 108435 & 170 & 5516 & 94 \\
\hline Dfb & 69046 & 22705 & 45 & 4044 & 33 \\
\hline Mag3 & 53791 & 8143 & 100 & 4213 & 28 \\
\hline GST & 1702 & 418 & 60 & 141 & 17 \\
\hline
\end{tabular}

Spleen adherent cells and B cells $\left(5 \times 10^{5} / \mathrm{ml}\right)$ were cultured with several stimulators for $18 \mathrm{~h}$, the culture supernatants were harvested, and cytokines in the culture supernatant were measured by ELISA. The results are expressed as mean pg cytokines produced by $5 \times 10^{5}$ cells in duplicate cultures. The production of IL- $1 \alpha, \mathrm{IL}-6, \mathrm{IL}-12$ by B cells were not detected. 
(A)
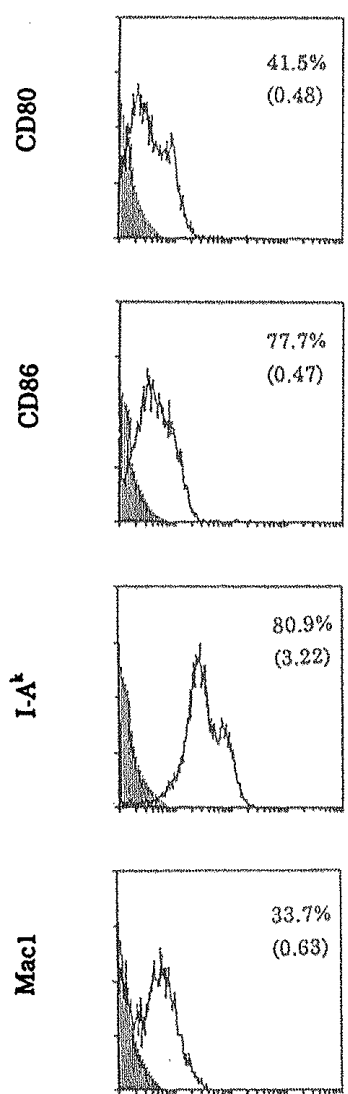

(B)
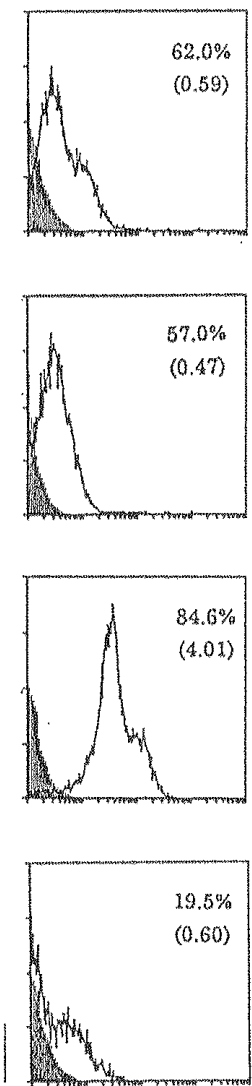

(C)
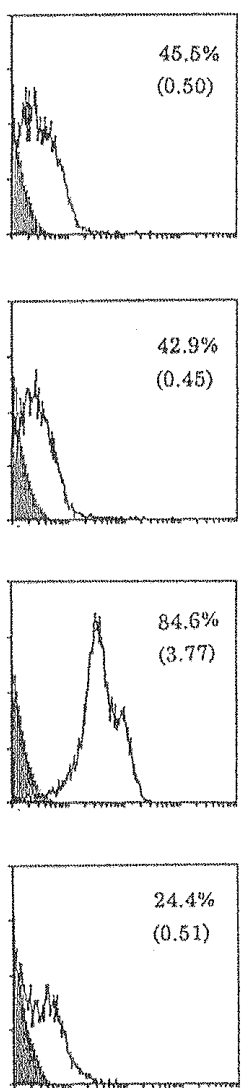

Fig. 4. Surface marker expression on spleen adherent cells. Spleen adherent cells were cultured with PBS (A), Dfb (B) or Mag3-GST (C) overnight, stained with fluorescein anti-CD80, CD86, I-A ${ }^{\mathrm{k}}$ or Mac 1 antibody, and analyzed by a flowcytometer. The results are expressed as the profile of fluorecein positive cells. Shadows show negative staining. The numbers in the figures are \%positive cells and mean fluorescence intensity.

\section{Discussion}

Dermatophagoides is one of the major allergens that induces allergic diseases in humans. Antigens prepared from Dermatophagoides have several immunological properties that react with serum antibody and stimulate $T$ cells from allergic patients $[1-3]$. In our previous papers we reported that mite antigens had an activity not only to specifically stimulate $T$ cells but also to nonspecifically stimulate B cells to proliferate and to produce immunoglobulin in mice $[9,10,11]$. In this study, we investigated the effect of mite antigens on antigenpresenting cells/macrophages from the standpoint of cytokine production and costimulatory molecule expression. In this experiment we used crude Dermatophagoides antigen(Dfb) 

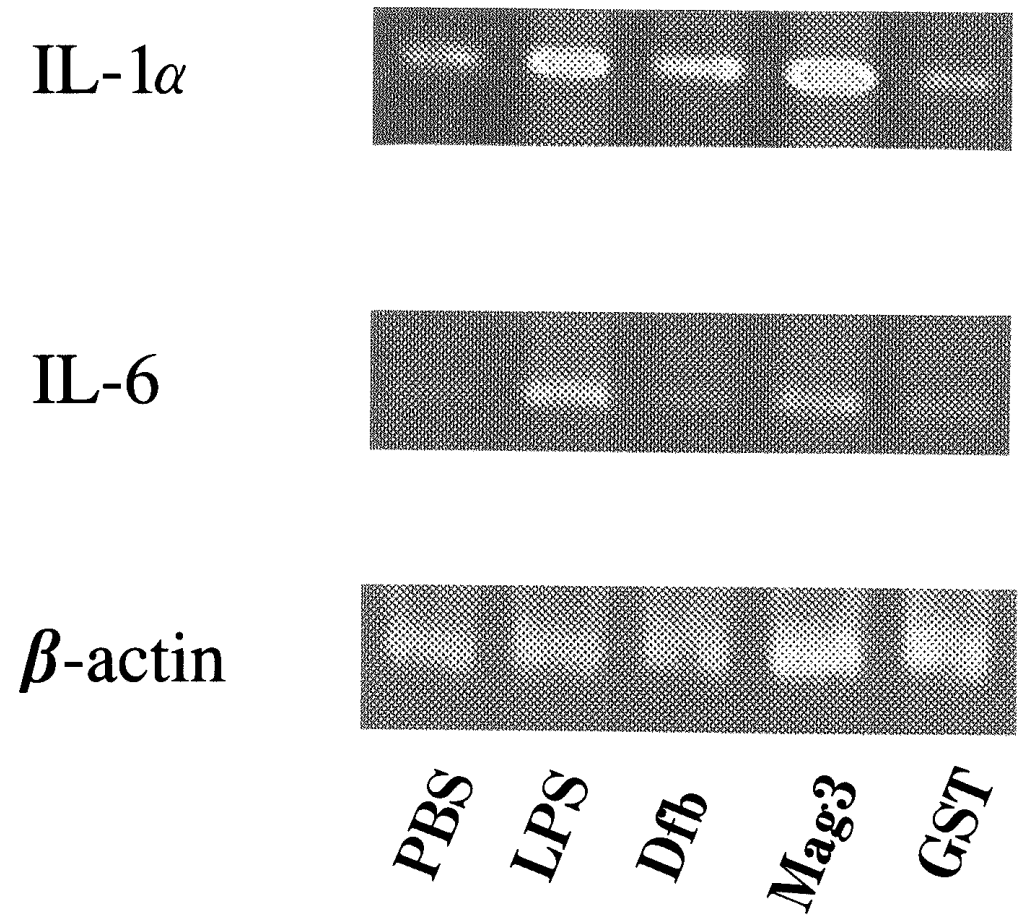

\section{B cells stimulated with}

Fig. 5. Cytokine mRNA expression in B cells stimulated with mite antigens. Purified B cells were stimulated with PBS, LPS, Dfb, Mag3-GST or GST for $6 \mathrm{~h}$. After mRNA was extracted, RT-PCR was performed, and PCR-products were electrophoresed. The results are expressed as ethidium bromidestaining bands of each cytokine.

and GST-fused recombinant antigen(Mag3) as antigens [7]. Dfb and Mag3 nonspecifically stimulated murine spleen cells to proliferate, confirming our previous report [10]. Responder cells to mite antigens were $\mathrm{B}$ cells, but not $\mathrm{T}$ cells, because the mite antigen response was sensitive to anti-Ig antibody and $C$ treatment, but not to anti-Thy 1 antibody and C treatment. A representative B cell mitogen is LPS. However, we confirmed that the B cell stimulating activity of mite antigens was not due to the contamination of LPS, because polymyxin B-column passed Dfb still retained B cell stimulating activity, and GST alone without Mag3 similarly prepared with Mag3-GST did not stimulate B cells. Polymyxin Bcolumn passed LPS markedly lost its B cell stimulating activity. Mite antigens stimulated B cells and spleen adherent cells to produce cytokines such as IL-1 , IL-6 , IL-10 and IL-12. It has been reported that in allergic patients $\mathrm{T}$ cells polarize to Th2 in which IL-4-production is increased and IFN- $\gamma$-production is decreased [19], and IL-12 production by monocytes, which is an important cytokine to induce Th1, is decreased in allergic patients [20]. Furthermore, the immunization of mice with Der p1 decreased IFN- $\gamma$-production and IgG2a 
antibody titer, while it did not affect IL-4-production and Ig isotype switching [21]. However, we could not detect any polarization of cytokine production at the antigen presenting cells/ macrophage level. Costimulatory molecules such as CD80 and CD86 play an important role in the antigen presentation $[22,23,24]$. Therefore, we studied the effect of mite antigens on the expression of costimulatory molecules on antigen presenting cells. Spleen adherent cells expressed $42 \%$ CD80, 78\% CD86 and 81\% MHC class II molecules on their surface. Mite antigens enhanced the expression of MHC class II molecules and CD80, but decreased that of CD86 on B cells and spleen adherent cells. In agreement with these results, B cells and spleen adherent cells treated with mite antigens more efficiently stimulated allogeneic $\mathrm{T}$ cells to proliferate (alloantigen presentation) and anti-CD80, CD86 and MHC class II antibodies inhibited their antigen presentation. Although the percentage of CD86 expression on adherent cells was decreased by mite antigen-treatment, the suppressive effect of anti-CD86 antibody on the alloantigen presentation was the same between mite antigen-treated and nontreated spleen adherent cells. This means that the reduced CD86 expression still has enough antigen-presenting activity. CD40 was not detected in our system (data not shown). In this experiment we used purified B cells and spleen adherent cells as antigen-presenting cells.

Spleen adherent cells contained about $80 \%$ MHC class II-positive cells and 35\% Mac 1positive cells and 10\% surface Ig-positive cells (B cells). We did not further purify the spleen adherent cells, because the further purification procedure nonspecifically stimulated cytokine production. Mite antigens similarly affected alloantigen presentation and CD80/ CD86 expression of purified B cells. However, purified B cells did not produce a large amount of cytokines when stimulated with mite antigens.

Recently it has been reported that mite antigens have cysteine protease activity which digests CD23 and CD25 and modulates immune responses [25, 26]. Furthermore, King et al. reported that mite antigens containing cysteine protease stimulated human airway epithelial cells to produce cytokines such as IL-6 and IL-8 [27]. The stimulation mechanism of antigen-presenting cells/macrophages with mite antigens, whether this is mediated by protease activity or by specific receptors on macrophages, will be the next subject of this study.

Antigen-presenting cells/macrophages are the initial cells that handle foreign substances. Accordingly, the evidence that mite antigens have an activity that stimulates antigen presenting cells/macrophages is an important finding when considering the mechanism of $T$ cell and $\mathrm{B}$ cell activation with mite antigens.

\section{References}

1. Arlian LG (1991) : House-dust-mite allergens: a review. Exp Appl Acarol 10: 167-186

2 . Platts-Mills TA, Thomas WR, Aalberse RC, Vervloet D \& Champman MD (1992) : Dust mite allergens and asthma: report of a second international workshop. J Allergy Clin Immunol 89 : $1046-1060$ 
3. Stewart GA (1995) : Dust mite allergens. Clin Rev Allergy Immunol 13 : 35-50

4. Aki T, Ono K, Paik SY, Wada T, Jyo T, Shigeta S, Murooka Y \& Oka S (1994) : Cloning and characterization of cDNA coding for a new allergen from the house dust mite, Dermatophagoides farinae. Int Arch Allergy Apply Immunol 103: 349-356

5. Aki T, Ono K, Hidaka Y, Shimonishi Y, Jyo T, Wada T, Yamashita M, Shigeta S, Murooka Y \& Oka $S$ (1994): Structure of IgE epitopes on a new 39-kD allergen molecule from the house dust mite, Dermaotphagoides farinae. Int Arch Allergy Apply Immunol 103 : 357-364

6. Aki T, Fujikawa A, Wada T, Jyo T, Shigeta S, Murooka Y, Oka S \& Ono K (1994): Cloning and expression of cDNA coding for a new allergen from the house dust mite, Dermatophagoides farinae: homology with human heat shock cognate proteins in the heat shock protein 70 family. J Biochem $115: 435-440$

7 . Fujikawa A, Ishimaru N, Seto A, Yamada H, Aki T, Shigeta S, Wada T, Jyo T, Murooka Y, Oka S \& Ono K (1996) : Cloning and characterization of a new allergen, Mag3, from the house dust mite, Dermatophagoides farinae: cross-reactivity with high-molecular-weight allergen. Mol Immunol 33: $311-319$

8. Aki T, Kodama T, Fujikawa A, Miura K, Shigeta S, Wada T, Jyo T, Murooka Y, Oka S \& Ono K (1995) : Immunochemical characterization of recombinant and native tropomyosins as a new allergen from the house dust mite, Dermatophagoides farinae. J Allergy Clin Immunol 96: 74-83

9. Fujii S, Ono K, Takeuchi A, Aki T, Shigeta S, Suzuki O, Jyo T \& Yamashita U (1997) : Identification of T-cell epitope sequences on an important mite antigen. Clin Exp Allergy 27 : 10861094

10. Fujii S, Ono K, Shigeta S, Jyo T \& Yamashita U (1997) : Human T cell responses to recombinant mite antigens of Dermatophagoides farinae. Clin Exp Immunol c108 : 284-288

11. Fujii S, Ono K, Shigeta S, Oka S, Jyo T \& Yamashita U (1996) : B cell mitogenic activity of house dust mite, Dermatophagoides farinae, antigens. Immunol Letters $49: 37-42$

12. Issekutz AC (1983) : Removal of gram-negative endotoxin from solution by affinity chromatography. J Immunol Methods 61 : 275-281

13. Yamashita U \& Hamaoka T (1979) : The requirement of Ia-positive accessory cells for the induction of hapten-reactive cytotoxic T lymphocytes in vitro. J Immunol 123 : 2637-2643

14. Corradin G, Etlingler HM \& Chiller JM (1977) : Lymphocyte specificity to protein antigens. I. Characterization of the antigen-induced in vitro $\mathrm{T}$ cell-dependent proliferative response with lymphonode cells from primed mice. J Immunol 119 : 1048-1055

15. Harrison MR, Thurmond GB \& Thomas GM (1974) : A simple and versatile harvesting device for processing radioactive label incorporated into and/or released from cells in microculture. J Immuno Methods 4: $11-20$

16. Segawa K, Ono K, Oka S, Jyo T, Kuroiwa A \& Yamashita U (1994) : B cell mitogenic activity of sea squirt antigen. Int Arch Allergy Immunol 104 : 270-276

17. Chomczynsky P \& Sacchi N (1987) : Single-step method of RNA isolation by acid guanidinium thiocyanate-phenol-chloroform extraction. Anal Biochem 162: 156-159 
18. Zar JH (1974) : Biostatistical analysis. Prentic Hall Inc., Englewood Cliffs, New Jersey 620 pp

19. Secrist H, Chelen CCJ, Wen Y, Marsball JP \& Umetsu DT (1993) : Allergen immunotherapy decreases interleukin 4 production in $\mathrm{CD}^{+}{ }^{+} \mathrm{T}$ cells from allergic individuals. J Exp Med 178 : $2123-2130$

20. van der Pouw Kraan TC, Boeije LC, de Groot ER, Stapel SO, Snijders A, Kapsenberg ML, van der Zee JS \& Aarden LA (1997) : Reduced production of IL-12 and IL-12-dependent IFN- $\gamma$ release in patients with allergic asthma. J Immunol 158 : 5560-5565

21. Comoy EE, Pestel J, Duez Cstewart GA, Vendeville C, Fournier C, Finkelman F, Capron A \& Thyphronitis G (1998) : The house dust mite allergen, Dermatophagoides pteronyssinus, promotes type 2 responses by modulating the balance between IL-4 and IFN- $\gamma$. J Immunol $160: 2456-$ 2462

22. Koulova L, Clark EA, Shu G \& Dupont B (1991) : The CD28 ligand B7/BB1 provides costimulatory signal for alloactivation of $\mathrm{CD}^{+}{ }^{+} \mathrm{T}$ cells. $\mathrm{J}$ Exp Med $\quad$ 173 : $759-762$

23. Azuma M, Cayabyab M, Buck D, Phillips JH \& Lanier LL (1992) : CD28 interaction with B7 costimulates primary allogeneic proliferative responses and cytotoxicity mediated by small, resting $\mathrm{T}$ lymphocytes. J Exp Med 175: 353-360

24. Hathcock KS, Laszlo G, Pucillo C, Linsley P \& Hodes RJ (1994) : Comparative analysis of B7-1 and B7-2 costimulatory ligands: expression and function. J Exp Med 180: 631-640

25. Schulz O, Laing P, Sewell HF \& Shakib F (1995) : Der $p$ 1, a major allergen of the house dust mite, proteolytically cleaves the low-affinity receptor for human IgE (CD23). Eur J Immunol 25 : 3191-3194

26. Schulz O, Sewell HF \& Shakib F (1998): Proteolytic cleavage of CD25, the $\alpha$ subunit of the human $\mathrm{T}$ cell interleukin 2 receptor, by Der p1, a major mite allergen with cysteine protease activity. J Exp Med 187: 271-275

27. King C, Brennam S, Thompson PJ \& Stewart GA (1998)：Dust mite proteolytic allergens induce cytokine release from cultured airway epithelium. J Immunol $161: 2645-2651$ 
抗原提示細胞/マクロファージの機能に及ぼすダニ抗原の影響

野口 順子', 黒田 悦史 ${ }^{1}$, 小埜 和久 ${ }^{2}$, 山下 優毅1

${ }^{1}$ 産業医科大学医学部 免疫学教室

${ }^{2}$ 広島大学工学部 発酵工学教室

要 旨： マウスのリンパ球とマクロファージの機能に対するダニ抗原の影響を in vitro で解析 した。コナヒョウヒダニ虫体から精製した抗原（Dfb）とGST一融合リコンビナント Mag3 ダ二抗原蛋白は，マウスの脾細胞の増殖反応を刺激した。この反応は，抗 Ig 抗体と補体の処理で低下するが，抗 Thy-1 抗体と補体の処理を受けないことから， 反応性細胞は B 細胞であると考えられた。ポリミキシン B カラムを通過した Dfb や， GST 蛋白のみではこの作用がないことから，ダニ抗原による刺激は代表的な B 細胞 マイトーゲンであるLPS の混在によるものではないと考えられた。ダニ抗原で処理 した B 細胞と脾付着細胞はアロ抗原提示能が充進していた．ダニ抗原の処理は，B 細胞，脾付着細胞上の MHC クラス II 分子と CD80の発現を増強したが, CD86の発 現は低下させた．MHC クラス II抗原，CD80，CD86に対する抗体はアロ抗原提示能 を阻害した。さらにダ二抗原は B 細胞と脾付着細胞のサイトカイン産生を増強した。 これらの事実はダ二抗原が抗原提示細胞/マクロファージの機能を刺激し，免疫反応 を修飾しうる能力があることを示している。

J UOEH（産業医大誌）22（3）：205－218（2000） 